\title{
Plastic Bronchitis Associated with Influenza: An Adult Case
}

\author{
Yuichi Murata, Sayoko Ishihara, Yoriko Sato and Takanori Ohta
}

Key words: influenza, plastic bronchitis, adult

(Intern Med 60: 1647-1648, 2021)

(DOI: 10.2169/internalmedicine.5313-20)

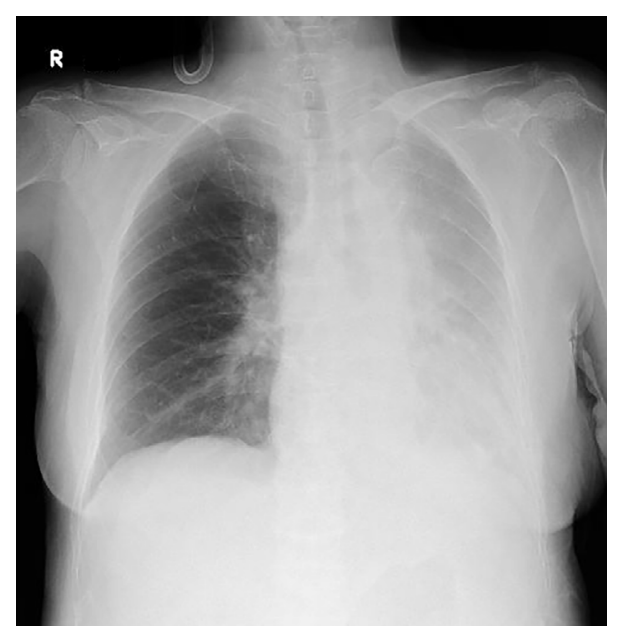

Picture 1.

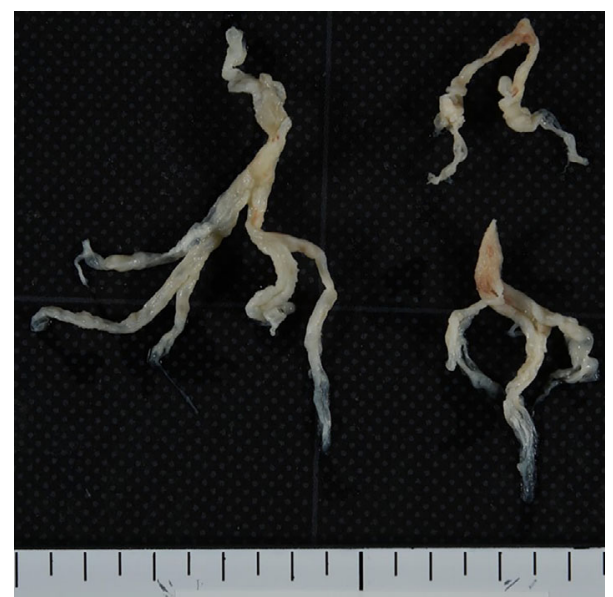

Picture 3.

A 74-year-old woman with multiple myeloma who complained of high fever was diagnosed with influenza A and immediately treated with laninamivir. Ten hours later, she developed dyspnea with bilateral wheezing, which progressed to type- 2 respiratory failure. Chest radiography re-

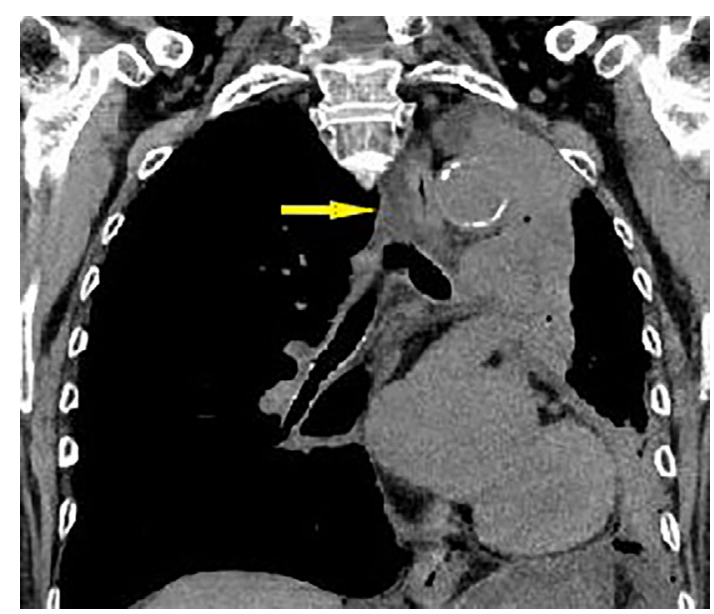

Picture 2.

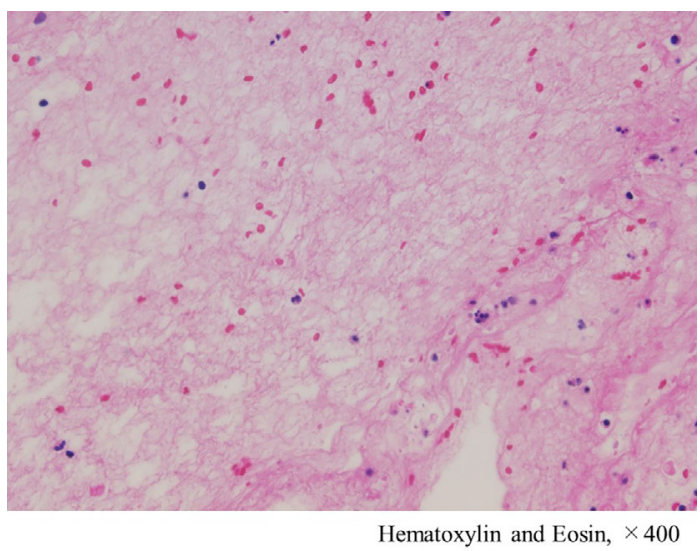

Picture 4.

Department of Internal Medicine, Kitakyushu Municipal Medical Center, Kitakyushu City Hospital Organization, Japan Received: May 12, 2020; Accepted: November 8, 2020; Advance Publication by J-STAGE: December 22, 2020 Correspondence to Dr. Takanori Ohta, t_oota01@kmmc.jp 
(Picture 3,4), which was not caused by an allergy or another disease. The influenza virus infection lasted for two weeks and was associated with the respiratory symptoms. PB was considered to be associated with severe influenza virus infection due to the patient's advanced age and immunocompromised status. PB is rarely associated with influenza virus infection, and mainly occurs during childhood $(1,2)$. PB should also be considered in adults if lung atelectasis develops after influenza virus infection.

The authors state that they have no Conflict of Interest (COI).

\section{References}

1. Bruce K Rubin. Plastic bronchitis. Clin Chest Med 37: 405-408, 2016.

2. Zhang J, Kang X. Plastic bronchitis associated with influenza virus infection in children: a report on 14 cases. Int $\mathrm{J}$ Pediatr Otorhinolaryngol 79: 481-486, 2015.

The Internal Medicine is an Open Access journal distributed under the Creative Commons Attribution-NonCommercial-NoDerivatives 4.0 International License. To view the details of this license, please visit (https://creativecommons.org/licenses/ by-nc-nd/4.0/).

(C) 2021 The Japanese Society of Internal Medicine Intern Med 60: 1647-1648, 2021 